\title{
MANAGEMENT STATUS OF MACKAREL (RASTRELLIGER SP.) RESOURCES IN THE FISH RESOURCES DOMAIN OF REMBANG DISTRICT, CENTRAL JAVA PROVINCE OF INDONESIA, AS A PART OF ECOSYSTEM APPROACH OF FISHERIES MANAGEMENT
}

\author{
Amin M. Nanang Nasrul*, Student \\ University of Diponegoro, Indonesia \\ Bambang A. Nur, Saputra S.W. \\ Faculty of Fisheries and Marine Sciences, University of Diponegoro, Indonesia \\ *E-mail: nanangnasrul@gmail.com
}

\begin{abstract}
Mackerel is an economically high and dominant fish caught in the waters of Rembang District. Its production volume is the third largest in 2017, by 2,013 tons. Mackerel is commonly caught using a small pelagic - one boat operated purse seine with a 30 GT boat down. Intensive fishing efforts will endanger the population of this fish, so management is needed so that fish resources can be sustainable. The study was conducted in Rembang District to see the status of mackerel (Rastrelliger sp.) resource management in the domain of fish resources with an ecosystem approach. It lasted from December 2018 to February 2019. It employed a survey method. The indicators used in the domain of fish resource are standard CPUE, trends in fish size, proportion of juvenile fish caught, catch species composition, range collapse of fish resources, and ETP species. The results showed that standard CPUE, trends in fish size, catch species composition, proportion of juvenile fish caught, and ETP species are in good condition with a score of 3 (green modeling flag). While the range collapse of fish resources is in a moderate condition, with a score of 2 (yellow modeling flag). The composite score of 97 shows that management status of Mackerel resources in the domain of fish resource in Rembang District is in very good condition (dark green flag modeling).
\end{abstract}

\section{KEY WORDS}

Mackerel, EAFM, Rembang, indicator, composite.

Rembang District at Central Java Province, Indonesia, having a coastline of $63.5 \mathrm{~km}$ in length, makes fisheries the dominant livelihood for its population. The coastal area is $35.5 \%$ of its total area, amounting to $355.95 \mathrm{~km} 2$. Of the 14 sub-districts, 6 of them are coastal subdistricts, i.e., Kaliori, Rembang, Lasem, Sluke, Kragan, and Sarang sub-districts. According to Minister of Marine Affairs and Fisheries Regulation (Permen) No.18/PERMEN-KP/2014, Rembang waters are included in the WPPNRI 712 or the Java Sea with utilization rates of 0.38 or classified as moderate (Ministerial Decrees of Marine Affairs and Fisheries Number or Kepmen Number 50/KEPMEN-KP/2017).

Rembang District has 10 (ten) active fishing ports, i.e., Tunggulsari, Tanjungsari, Tasikagung I, Tasikagung II, Banggi Market, Pangkalan, Pandangan, Karang Lincak, Karanganyar, and Sarang (Rembang Department of Maritime Affairs and Fisheries or DKP Rembang, 2017). A total of 6 (six) fishing ports are included in the Ministerial Decrees of Marine Affairs and Fisheries No. 6/KEPMEN-KP/2018, i.e., Karanganyar, Pandangan, Pangkalan, Sarang, Tanjungsari, and Tasikagung Fishing Ports.

The total production of marine fisheries in Rembang District in 2017 amounted to 36,243 tons with a production value of Rp.410.8 billion. The dominant types of fish are Layang fish (Decapterus macrosoma), Black Bawal (Formio niger), Mackerel (Restrelliger brachysoma), Selar (Selaroides leptolepis), Tembang/Jui (Sardinella fimbriata), Eastern little tuna (Auxis thazard), Spanish Mackerel (Scomberomous lineatus), and Squid (Loligo sp.). 
Mackerel (Rastrelliger brachysoma) production is the third largest by 2,013 tons with a production value of 30.5 billion rupiahs (DKP Rembang, 2017).

Mackerel (Rastrelliger brachysoma) production trend in Rembang in 9 (nine) years showed a decline, which was 3,847 tons in 2009 and 2,013 tons in 2017. As proposed by Suwarso, et al. (2007) in Suwarso, et al. (2015) that in the last few years, there has been a shift in the fishing area to the west accompanied by changes in fishing targets due to the lower catch. Although in the macro scale, the potential of pelagic fish resources in WPPNRI 712 is in the moderate status.

One model of fisheries management is Fisheries Management with an Ecosystem Approach. This model was developed with a balanced purpose among all components of habitat and ecosystem including involving the community at large (Ward et al. 2002; Berkes, 2012) and socio-economic (FAO, 2003). According to Yulianto (2010), this model takes into account all the linkages between fish resources, habitats, fisheries actors' interventions, government, and economic actors related to fish resource commodities, and to improve the existing management quality (conventional management) (Gracia and Cochrane, 2005). Thrush and Dayton (2010) suggested that EAFM was to address the increasingly complex problems of managing coastal and marine resources while taking into account the socioeconomic and ecological aspects.

Based on the background above, it needs to do research to develop a concept of sustainable resource management with an ecosystem approach. This study focuses on the domain of fish resources. The domain uses 6 indicators, namely (1) standard catch per unit effort (CPUE), (2) size of fish, (3) proportion of juvenile caught, (4) species composition, (5) range collapse of fish resources, and (6) ETP (Endangered, Threatened, and Protected) species. These six indicators will indicate the management status of Mackerel resources (Rastrelliger sp.), so the further management action plans can be formulated.

\section{MATERIALS AND METHODS OF RESEARCH}

Some criteria set by the writers to be the object of the research are (1) to be the fishing boat owners/captain/crew domiciled in Rembang District, (2) to have a ship with $\leq 30$ GT with small pelagic - one boat operated purse seine, (3) to have fish landing base in Sarang, Karanganyar and Pandangan, (4) to target mackerel as the cath.

This study employed a survey method. It is carried out through a purposive sampling approach, which is by contacting and interviewing respondents considered to have extensive information and knowledge about the development of fish catches in the observed waters. Respondents were fishermen (owners/captain/crew) domiciled in the study area as many as 48 people.

Purposive sampling was used to determine the location based on the dominance of ships with small pelagic - one boat operated purse seine in Central Java, precisely Rembang District. Meanwhile, random sampling was applied for ships and fish. It depends on the ship landing the catch at the time of sample collection. The number of samples obtained was 25 ships and 503 fish. Sampling was carried out from December 2018 to February 2019 (3 months) at Sarang, Karanganyar, and Pandangan Fish Landing Base.

The data collected is primary and secondary data. Primary data includes the length and weight of mackerel caught, catchment area, and the type of ETP species caught. Secondary data includes the number of active vessels, the number of production (2009-2017), and the number of trips (2009-2017). Primary data was obtained through interviews and measurements of sample fish lengths. Interviews were conducted with respondents using a questionnaire guide. Measuring the length and weight of fish, for example, is done once a week in December 2018-February 2019 a using block millimeter and digital scales. Secondary data was obtained through reference studies from Central Java Marine Affairs and Fisheries Department, Rembang Marine Affairs and Fisheries Department, Cilacap PSDKP (Maritime and Fisheries Monitoring Task Force) Station, and Rembang Central Bureau of Statistics. Briefly, the methods and criteria are presented in Table 1. 
Table 1 - Indicator, Methodology, and Domain criteria of Fish resource

\begin{tabular}{|c|c|c|c|}
\hline No & Indicator Attribute & Methodology / Data collection & Criteria \\
\hline 1 & Standard CPUE & $\begin{array}{l}\text { Statistical data of time series } \\
\text { minimum of } 5 \text { years }\end{array}$ & $\begin{array}{l}1=\text { CPUE drops sharply }(>25 \%) \\
2=\text { CPUE decreases slightly }(<25 \%) \\
3=\text { CPUE is stable or increases }\end{array}$ \\
\hline 2 & Fish size & $\begin{array}{l}\text { Interviews and sampling } \\
\text { of length measurements } \\
\text { at fish auction houses }\end{array}$ & $\begin{array}{l}1=\text { Crab size is getting smaller } \\
2=\text { relative fixed size } \\
3=\text { bigger size }\end{array}$ \\
\hline 3 & $\begin{array}{l}\text { Proportion of juvenile fish } \\
\text { caught }\end{array}$ & Interview & $\begin{array}{l}1=\text { numerous }(>60 \%) \\
2=\text { lots }(30-60 \%) \\
3=\text { little }(<30 \%)\end{array}$ \\
\hline 4 & Species composition & Interview and observation & $\begin{array}{l}1=\text { target fish proportion is smaller } \\
2=\text { target fish proportion is similar to the non target } \\
3=\text { non-target fish proportion is greater }\end{array}$ \\
\hline 5 & Range collaps & Interview & $\begin{array}{l}1=\text { Fishing ground is very far away } \\
2=\text { Fishing ground is far away } \\
3=\text { Fishing ground is relatively fixed }\end{array}$ \\
\hline 6 & ETP Species & Interview & $\begin{array}{l}1=\text { ETP species caught but not released; } \\
2=\text { caught but released } \\
3=\text { there are no ETP species caught }\end{array}$ \\
\hline
\end{tabular}

Source : Adrianto, et al (2014).

This study used a method that refers to the Implementation Instructions of Indicator Assessment of Fisheries Management with Ecosystem Approach composed by Adrianto, et al. (2014) and ratified in the Decree of Directorate General of Capture Fisheries Number 18/KEP-DJPT/2014.

Flag modeling technique uses a multi-criteria analysis (MCA) approach. A set of criteria is built as the basis for performance analysis of fisheries management areas viewed from the Ecosystem Approach to Fisheries Management (EAFM), through the development of composite index with the following stages: (Adrianto, Matsuda, and Sakuma. 2005).

- Determine criteria for each indicator in each domain of fish resource;

- Score on each indicator using ordinal based Likert Scores 1, 2, and 3;

- Determine the weight for each indicator.

From those six indicators, standard CPUE is the most important indicator with a weight value of $40 \%$. Then, it is followed by trends in fish size $(20 \%)$, proportion of juvenile fish caught $(15 \%)$, species composition (10\%), range of collapse of fish resources $(10 \%)$ and ETP species (5\%).

Later on, it was analyzed using simple arithmetic-average based composite analysis with the values between 100 and 8700 . Later on, the values of 100-8700 are classified as 1100 percent. The percentage value obtained is plotted in table 2 below.

Table 2 - Flag Modeling Category for EAFM Assessment

\begin{tabular}{cccc}
\hline \multicolumn{2}{c}{ Range of Values (in percent) } & \multirow{2}{*}{ Flag Model } & \multirow{2}{*}{ Description } \\
\hline Lowest range & Highest range & & Not applying EAFM yet \\
22 & 21 & Red & Less applying EAFM \\
42 & 41 & Light yellow & Is applying EAFM \\
61 & 60 & Yellow & Good to apply EAFM \\
81 & 80 & Light greem & Excellent to aply EAFM \\
\hline
\end{tabular}

Source : Adrianto, et al (2014).

\section{RESULTS AND DISCUSSION}

Production, trip, and catch per trip (CPUE) of Mackerel based on small pelagic - one boat operated purse seine and cantrang (seine nets) in Rembang District are presented in Table 3 and Figure 1. While production and trip relations are presented in Figure 2.

Table 3 and Figure 1 shows that production tends to increase, while the number of standard trips tends to decrease, so CPUE tends to increase for 7 years (2010-2016). The average value of CPUE changes by $26.8 \%$ means that the CPUE indicator tends to increase 
(Adrianto, et al. 2014). Maximum Sustainable Yield (MSY) value by 66,244 tons/year and Optimum Yield by 52,979 tons/year reveal that mackerel resources are thought to have overfishing. Based on the description above, the CPUE indicator is scored 3.

According to the interview results, the minimum number of catches by $5310.3 \mathrm{~kg} / \mathrm{trip}$ using small pelagic - one boat operated purse seine and an average boat size of 24 GT does not damage fishermen or at least reaches Break Even Point (BEP). The number of catches is strongly influenced by boat engines and fishing gear. Diah et al. (2018) state that the factor of technological advancement of the fishing fleet (engines and fishing gear) also influence the increase in catches.

Table 3 - Production data and CPUE

\begin{tabular}{cccccc}
\hline No. & Year & Total production $(\mathrm{kg})$ & Total trip & Standard CPUE & Percentage of changes (\%) \\
\hline 1 & 2010 & 37.775 .613 & 5.151 & $7.334,29$ & $123,7 \%$ \\
2 & 2011 & 56.100 .875 & 3.420 & $16.405,51$ & $23,9 \%$ \\
3 & 2012 & 64.894 .513 & 3.191 & 20.334 .42 & $-6,7 \%$ \\
4 & 2013 & 63.770 .611 & 3.363 & $18.964,47$ & $16,8 \%$ \\
5 & 2014 & 67.612 .628 & 3.053 & $22.143,65$ & $13,4 \%$ \\
6 & 2015 & 66.522 .874 & 2.650 & $25.100,39$ & $-10,4 \%$ \\
7 & 2016 & 72.757 .867 & 3.234 & $22.500,96$ & $26,8 \%$ \\
\hline \multicolumn{7}{c}{ Average }
\end{tabular}

Source : Statistical data of DKP Rembang in 2010-2017.

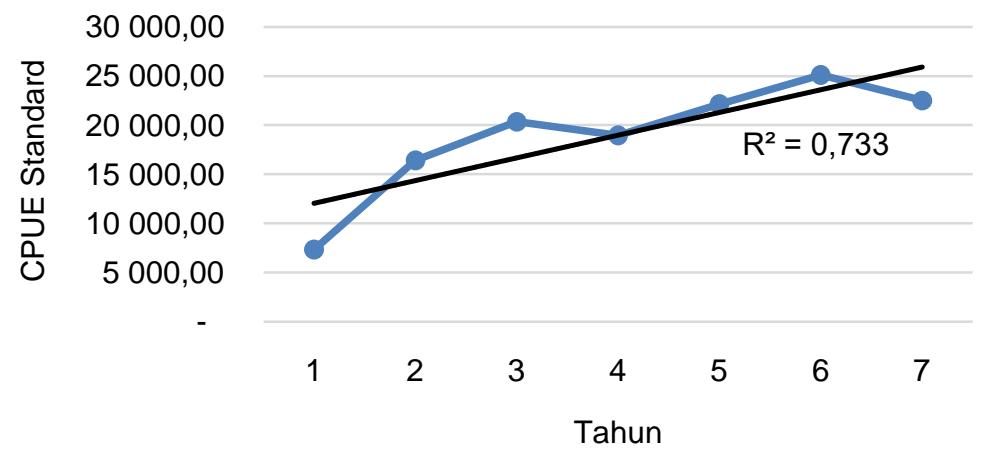

Figure 1 - Standard CPUE graph of 2010 - 2016

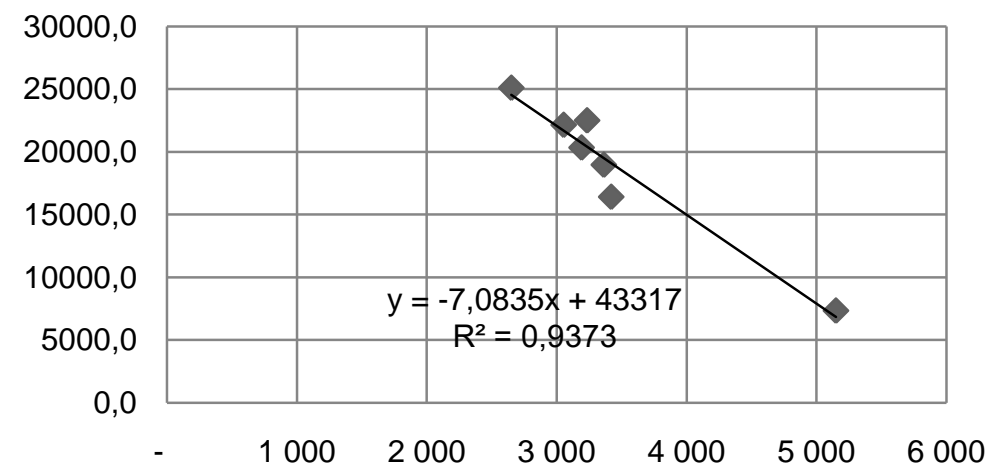

Figure 2 - CPUE relationship graph with total capture effort

Trends in fish size. The research data shows that from 48 respondents, $65 \%$ (31 respondents) said that in the last 5-10 years, trends in mackerel size caught and landed at Sarang, Karanganyar and Pandangan Fish Landing Base was relatively constant. Total Length (TL) data of sample fish is mostly $21.34 \mathrm{~cm}$. Compared to the data of first fish size mature gonads $(\mathrm{Lm})$ at www.fishbase.org by $17 \mathrm{cmTL}$ and the study by Suwarno, et al. (2015) of $16.4 \mathrm{~cm}$, so the value obtained at this time is higher. Therefore, it can be assumed that the average fish is those allowed to catch and the fishing equipment used is 
environmentally friendly. Such conditions indicate that fish have enough time to grow up, even to spawn. This is in accordance with what Diah, et al. (2018) state that stuck fish size for 5 years indicates that fish have enough time to grow before being caught and have a small threat to the sustainability of fish resources. Therefore, trends in fish size indicator are scored 3.

Juvenile proportion caught. Of the 48 respondents, as many as 39 or $81 \%$ of them answered to catch a very little juvenile fish. Based on this, the score of this indicator is 3 . This is because the fishing gear used is the environmentally friendly one with the mesh size of $25 \mathrm{~mm}, 800$ buoys, and $210 \mathrm{~m}$ rope length. As stipulated in Permen KP Number 71/MEN$\mathrm{KP} / 2016$, that small pelagic - one boat operated purse seine have mesh size specifications $\geq$ 1 inch, rope rises $\leq 400$ meters, and use ABPI in the form of lights with a total power of $\leq$ 8000 watts. Suhartono, et al. (2013) propose that one of the most effective fishing gears is a purse seine or trawl ring.

Catch Species Component. According to the interview result, mostly fish caught with small pelagic - one boat operated purse seine is Layang fish, Mackerel, Small Tuna, Juwi fish, Spanish mackerel, and squid. These fish are the target of fishing vessels with small pelagic - one boat operated purse seine. Based on statistical data, the average production of mackerel is $5.5 \%$ of the total production fish caught using small pelagic - one boat operated purse seine and cantrang. This is because the fishing gear is environmentally friendly as stipulated in Permen KP No.71/MEN-KP/2016. Based on the description above, the idicator score of catch species composition is 3 .

Range collapse of fish resource. Based on the results of interviews, 18 or $37 \%$ of respondents said that fishing ground is getting further. They are looking for a fishing ground based on the information of fish presence from other fishermen. They dominate Karimunjawa Island, Masalembu Island, and Bawean Island, or generally, the northern sea of Java. This can be suspected because of environmental change, especially oceanography factor. As submitted by Suhartono, et al. (2013) that oceanography causes fish to choose places according to their physiological conditions as a form of adjustment to the environment that is beneficial to their existence.

Legally, fishermen are actually not allowed to catch up to around Bawean and Masalembu Island. That is because the ship used is 30 GT down. That kind of ship can only be operated at line II and III in WPPNRI 712 in Central Java Province (Permen KP Number $71 / 2016)$. It signifies that the fishing areas change according to the target species. Based on the description above, the score is 2 .

ETP Species. Based on the results of interviews with 48 respondents, all respondents $(100 \%)$ said that there are no ETP species caught using small pelagic - one boat operated purse seine, so the indicator score was 3 . The fishing gear used by fishermen is still environmentally friendly one and according to specifications stipulated in Permen KP Number 71/MEN-KP/2016. Therefore, fishing activities with certain gears do not have a negative impact on ETP species (Adrianto, et al. 2014).

Aggregate Assessment. Assessment results of the domain in Mackarel (Rastrelliger sp.) resources consisting of several indicators: (1) Standard catch per unit effort (CPUE), (2) Size of fish, (3) Proportion of juvenile fish caught, (4) Composition species, (5) Range collapse of fish resources, and (6) Endangered, Threatened or Protected species (ETP) are presented in Figure 4.

6. Endangered, Threatened or Protected.

5. Range collapse of fish resources

4. Composition species

3. Proportion of juvenile fish caught

2. Size of fish

1. Standard catch per unit effort (CPUE)

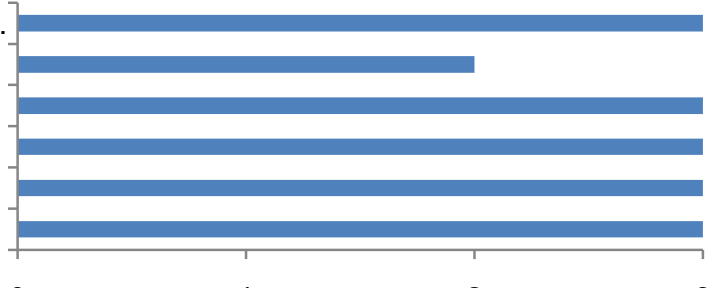

0 1 2

Figure 4 - Score assessment graph on the fish resource domain 
Figure 4 shows that the indicator of fish resources domain for mackerel resource management is in good condition. Range collapse indicator of fish resources is 2 or having yellow flags. Standard CPUE, fish size trends, catch species composition, juvenile fish proportion caught, and ETP worth 3 or having green flags. From these results, the indicators that are taken into account are the yellow indicators, namely the range collapse of fish resources. It is followed by calculating the composite value, as presented in Table 4.

Table 4 - Composite value calculation of fish resources domain

\begin{tabular}{|c|c|c|c|c|c|}
\hline Indicator & Score & Weight & Rank & Density & Value \\
\hline Standard CPUE & 3 & 40 & 1 & 29 & 3480 \\
\hline Trends in fish size & 3 & 20 & 2 & 29 & 1740 \\
\hline Proportion of juvenile fish caught & 3 & 15 & 3 & 29 & 1305 \\
\hline Capture species composition & 3 & 10 & 4 & 29 & 870 \\
\hline Range collapse of fish resources & 2 & 10 & 5 & 29 & 580 \\
\hline ETP Species & 3 & 5 & 6 & 29 & 435 \\
\hline & & \multicolumn{3}{|c|}{ Total Score } & 8410 \\
\hline & & \multicolumn{3}{|c|}{ Lowest total score } & 100 \\
\hline & & \multicolumn{3}{|c|}{ Highest total score } & 8700 \\
\hline & & \multicolumn{3}{|c|}{ Composite value } & 97 \\
\hline & & \multicolumn{3}{|c|}{ Description } & Excellent \\
\hline
\end{tabular}

Action plan for improvement. Assessment results of the indicators above are an illustration of EAFM-based Mackerel resource management from the fish resource domain. The next step is the preparation of a corrective action plan for each EAFM indicator.The action plan for this improvement is in the form of recommendations for plans/activities to be carried out in order to improve fisheries management from the bad category (red) to moderate (yellow), and from the medium category (yellow) to the good category (green). The implementation of the management action plan is carried out in several stages (short, medium and long term) prioritizing those categorized bad (red). The corrective action plan for each indicator is presented in Table 5.

Table 5 presents a remedial action plan for short-term management of Mackerel resources. This domain is one of the other 6 domains in EAFM-based management, i.e., habitat and ecosystem domains, fishing technique, social, economic, and institutional.

Standard CPUE indicator is worth 3, meaning that the CPUE trend tends to increase. This is in accordance with Kepmen KP Number 50/KEPMEN-KP/2017 that the utilization rate of small pelagic fish in the Java Sea (WPP-712) is 0.38 and the number of catches allowed is 291,730 tons. Steps to maintain the conditions for the next 5 years are controlling the allocation of fishing vessels with small pelagic - one boat operated purse seine through licensing in accordance with Law Number 23 Year 2014. In addition, it is possible to carry out a study of fish resource allocation and allocation of fishing businesses based on the Decree of Directorate General for Capture Fisheries Number 86/KEP-DJP/2018.

Trend in fish size is worth 3 , meaning that it is getting bigger. Steps to try to maintain fish size like the current condition is to familiarize fishermen to keep using small pelagic one boat operated purse seine with a minimum mesh size of 1 inch according to the Permen KP Number 71/2006. According to Boesono, et al. (2016), the mini purse seine fishing gear must refer to the existing technical provisions. In addition, in case of a long-term period, it can protect nursery ground, among others, by zoning.

Proportion of juvenile fish caught is worth 3 , meaning that its proportion to catch is small. This means that the net size used by fishermen is in accordance with what required by the Minister of Marine and Fisheries Regulation Number 71/2016. This needs to be maintained by familiarizing and raising awareness about the use of the environmentally friendly fishing gear (Budiarto, 2015; Saputra, 2008). In addition, it is necessary to conduct regular supervision by the law enforcement officers (APH) both Maritime and Fisheries Monitoring Task Force (PSDKP), Provincial Department of Marine Affairs and Fishery (DKP), Water police (Sat-polair), and Navy.

Indicators of catches species composition are worth 3, meaning that the composition of target proportion is much more $(31 \%>$ of total volume) and there is no non-target species 
caught. Steps taken by disseminating information of fishing technology is able to reduce nontarget species. Diah, et al. (2018) state that it needs to control the capture of non-target species, assessment of fishing technology that reduces non-target species, and the application of fishing technology which reduces the capture of non-target species.

Table 5 - Corrective action plan for each indicator in the fish resource domain

\begin{tabular}{|c|c|c|c|c|c|}
\hline \multirow{2}{*}{ Indicator } & \multicolumn{2}{|r|}{ Actual Value } & \multicolumn{2}{|r|}{ Reference Indicator } & \multirow{2}{*}{ Tactical Step of Management } \\
\hline & Score & Criteria & Score & Criteria & \\
\hline Standard CPUE & 3 & CPUE is stable or even increases & 3 & CPUE is stable or even increases & $\begin{array}{l}\text { Control of additional ship allocations } \\
\text { through licensing is in accordance } \\
\text { with the authority (Law No.23/2014) } \\
\text { begins in the 1st year }\end{array}$ \\
\hline Fish size trend & 3 & The size trend is getting bigger & 3 & The size trend is getting bigger & $\begin{array}{l}\text { Disseminating information to } \\
\text { fishermen to keep using nets with a } \\
\text { minimum size of } 1 \text { inch mesh begins } \\
\text { from the } 1 \text { st year. }\end{array}$ \\
\hline $\begin{array}{l}\text { Proportion of } \\
\text { juvenile fish } \\
\text { caught }\end{array}$ & 3 & $\begin{array}{l}\text { The proportion of juvenile fish } \\
\text { caught is small }(<30 \%)\end{array}$ & 3 & $\begin{array}{l}\text { The proportion of juvenile fish } \\
\text { caught is small }(<30 \%)\end{array}$ & $\begin{array}{l}\text { Increasing awareness of the use of } \\
\text { environmentally friendly fishing gear } \\
\text { (Budiarto, 2015) begins in the 1st } \\
\text { year }\end{array}$ \\
\hline $\begin{array}{l}\text { Catch species } \\
\text { composition }\end{array}$ & 3 & $\begin{array}{l}\text { Target composition of proportions } \\
\text { is much more ( }>31 \% \text { from total } \\
\text { volume). }\end{array}$ & 3 & $\begin{array}{l}\text { The composition of the target } \\
\text { proportion is more }(>31 \% \text { of the } \\
\text { total volume) }\end{array}$ & $\begin{array}{l}\text { Fishing socialization technology to } \\
\text { reduce non-target species (Diah, et } \\
\text { al., 2018) begins since year } 1 .\end{array}$ \\
\hline $\begin{array}{l}\text { Range collapse of } \\
\text { fish source }\end{array}$ & 2 & $\begin{array}{l}\text { Fishing ground is far away, } \\
\text { depending on the target species }\end{array}$ & 3 & $\begin{array}{l}\text { Fishing ground is relatively fixed, } \\
\text { depending on the target species }\end{array}$ & $\begin{array}{l}\text { Socialization and regular installation } \\
\text { of fish houses managed in groups } \\
\text { start in the 1st year }\end{array}$ \\
\hline ETP Species & 3 & There are no ETP species caught & 3 & There are ETP species caught & $\begin{array}{l}\text { Raising awareness and conducting } \\
\text { socialization to fishermen to not } \\
\text { catch ETP species begins in the 1st } \\
\text { year }\end{array}$ \\
\hline
\end{tabular}

Furthermore, at the range collapse indicator, fish resources are worth 2 , meaning that the fishing area is far away from the target species. Fishermen catching fish around the Masalembu island has violated the license and can be sanctioned if caught. In order to revitalize fish resources, it can install fish houses in certain locations to provide space for fish to find food and grow large.

The value of ETP species is good. The steps must be maintained by increasing awareness and familiarizing fishermen to not catch ETP species. The awareness of the involved parties aims to ensure that regulations can be implemented properly (Saputra, 2008).

\section{CONCLUSION}

Management status of mackerel resource in the domain of fish resources in Rembang District with EAFM approach has a composite value of 97 . Its flag modeling is dark green meaning that it is excellent at implementing fisheries management with an ecosystem approach. Some indicators of CPUE, trends in fish size, composition of fish caught, proportion of juvenile fish caught, and ETP species are worth 3 . While range collapse of fish resources with medium criteria is worth 2 .

\section{REFERENCES}

1. Adrianto, L. M. 2005.Assessing Sustainability of Fisheries Systems In A Small Island Region. Proceedings of IIFET. Tokyo: IIFET.

2. Adrianto, L., Habibi, A., Fahruddin, A., Azizy, A., Susanti, H. A., Musthofa, I. 2014.Modul Indikator untuk Pengelolaan Perikanan Dengan Pendekatan Ekosistem. Jakarta: Kementerian Kelautan and Perikanan.

3. Berkes F. 2012. Implementing Ecosystem-Based Management: Evolution Or Revolution. Fish and Fisheries, 13:465-476. 
4. Boesono, H., Setiawan D.R., Prihantoko, K.E., Jayanto, B.B, Malala, A.R. (2016). Productivity Analysis of Mini Purse Seine in PPI Pulolampes Brebes, Central Java, Indonesia. Aquatic Procedia 7(2016), 112-117.

5. Budiarto, A. 2015.Pengelolaan Perikanan Rajungan Dengan Pendekatan Ekosistem di Perairan Laut Jawa (WPPNRI 712). Unpublished Thesis. Bogor: Institut Pertanian Bogor.

6. Diah, A.P. Razak, A. Fahrizal, A. \& Irwanto. 2018. Status Pengelolaan Perikanan Dengan Pendekatan Ekosistem (P3E) pada Domain Sumberdaya Ikan untuk Komoditas Udang di Kabupaten Sorong Selatan Provinsi Papua Barat. Jurnal Airaha, 7 (2), 047-059.

7. [DKP Rembang] Dinas Kelautan and Perikanan Kab.Rembang. 2017. Statistik Perikanan Tangkap Tahun 2017. Rembang: Dinas Kelautan and Perikanan.

8. [FAO] Food and Agricultural Organization. 2003. Fisheries Management 2, The Ecosystem Approach To Fisheries. FAO of The United Nations, Rome, 112 p.

9. Gracia SM, Cochrane KL.2005.Ecosystem Approach to fisheries :A review of Implementation Guidelines. ICES Journal of Marine Sciences (62).

10. Istiani Wahid, N., Noviyanti R. \& Riani, E. 2019. Pengelolaan Perikanan Pelagis Besar Dengan Pendekatan Ekosistem di Kabupaten Mamuju Utara Sulawesi Barat. Jurnal Matematika, Sains, and Teknologi, 20 (1), 30-44.

11. Saputra, S.W. 2008. Biologi, Dinamika Populasi and Pengelolaan Udang Metapenenus elegans de Man 1907 di Laguna Segara Anakan Cilacap Jawa Tengah. Semarang: Badan Penerbit Universitas Diponegoro.

12. Suhartono, Haruna, B.Paillin, J. 2013. Identifikasi and Prediksi Daerah Penangkapan Ikan Kembung (Rastrelliger spp.) Di Perairan Kabupaten Pangkep. Jurnal "Amanisal" PSP FPIK Unpatti Ambon, 2 (2), 55-65.

13. Suwarso, 2015. Biologi Reproduksi and Dugaan Pemijahan Ikan Kembung (Ratreliger brachyosoma) Di Pantai Utara Jawa.Jurnal Bawal, Jakarta 7(1) 9-16.

14. Thrush SF, Dayton PK. 2010. What Can Ecology Contribute To Ecosystem-Based management. Annual review of marine science, annurev-marine-120308081129

15. Ward T, Tarte D, Hegerl E, Short K. 2002. Policy Proposals And Operational Guidance For Ecosystem-Based Management Of Marine Capture Fisheries. Melbourne: WWF for nature Australia.

16. Yulianto I. 2010.Pendekatan Ekosistem Untuk Pengelolaan Perikanan Karang di Pulau Weh Nangroe Aceh Darussalam. Unpublished Thesis. Bogor: Institut Pertanian Bogor. 